\section{PRESIDENTIAL ADDRESS,}

\section{Dolivered at the Annual Mreeting of the Obstetrical Society of London.}

BY J. MATTHEWE DUNCAN, M.D., LL.D., F.R.S.E., etc., President of the Society.

AETER a brief mention of the Fellows of the Society who had died since the last annual meeting, an enumeration of the papers read before the Society during the year, an announcement of the intended removal of the Society's library to more suitable premises, and a eulogy of his successor (Dx. H. Gervis), Dr. Duncan proceeded:

This great Society has many furctions to fulfil, and of these not the least important is a moral one, which gets little place in our statement of "objeots", and which has, for two years, occupied no part of our time. On, happily, very rare and'extraordinary occasions, the Society may be called upon to censure and even expel a Fellow, thus exercising moral discipline in a decided manner; but it wisely avoids discussion of such matter, and keeps within very narrow limits the direct exercise of control over its members, leaving this branch of medical police to the Colleges of Physicians and of Surgeons, who have long taken charge of it. But silence does not indicate forgetfulness or low estimation; and our active juristical interference, concerned as it has been only with minor disorders in. individuals; gives no indication of the supreme importance of our moral interests as a society. In no way can we, or do we, do more good than by increasing and diffusing a kindly spirit and mutual goodwill in our ranks. Nothing contributes more to our dignity and our success than sense of honour and love of truth. By promoting seience, we increase the weight and power of truth. Without high moral qualities in the practitioner-qualities of heart and of headthe work he does will all be tainted by his imperfections, and correspondingly fall short in its utility to his patients, his profession, and to himself. The intellect may be stared, the judgment may be sound, the hands may be skilful; yet the work does not reach an attainable degree of perfection if the heart is not right.

The promotion of soience is arowedly our great object, and accordingly it is our chief performance. The work has been done in previously announced papers and in casual contributions. Of these, some have been purely scientific, or, in the view of the mere practical man, apparently useless; some have been more or less practical or immediately useful, or intended to be so. We want still a great increase of the, at first sight, useless kind; and we shall hold it the best evidence of the progress of the Society that they appear and are cordially received. A great master of medical methodHelmholtz-has said, that he who pursues science with practical results in view will pursue in vain. The papers combining practical ends with scientific elaboration have been admirable, and must be useful and honourable to us. This Society will always regard such papers as deserving of encouragement, but they need no special fostering care, for the fruits of their application in practice are a sufficient stimulus, sometimes more than sufficient. The more this kind of utility is paramount, the less is scientific severity, and the greater the departure from the guidance of. logic, and consequently the less reliability. A great result, indeed, of our scientific work has been to show ns what we should not expect to be able to do, and what we should avoid attempting or doing.

Besides scientific and mixed scientific and practical papers, we have had before us proposals purely therapeutical, and several histories "of splendid work in practice. The surgical achievments which find place in our Transactions are as brilliant and wonderful and successful as any to be found in the history of the art. They show what:skill; guided by science, can dare and do; and the novel operations contribute, in this and other ways, to the solution of important practical problems: That a thing bean be done successfally, is not enough, however, to shot that it should be done. It is not juxlicious to excise the aterus in elderly women in order to prevent cancer of it. For myself, I have no doubt that the novel operations or series of them which have, in last session, been laid before us, iwill not be, in any sense, without good fruit, helping towards a sound judgment as to the extent or the limits of their applicability.

It is natural that the ingenious and bold surgoons who devise and axecute new operations should press them strongly upon the profeission, demanding quick approval, and it is to be lamented that they should sometimes misconstrue the relative slowness or silence - of-their brethren. Were new therapentical proposals to be quickly adopted, our whole practice would, by their number and variety, be brought into utter confusion. The silence or slowness of the profession regarding them is a kind and useful reception, for nothing more violent is required to secure for most of them speedy oblivion; while the stronger and better few, surviving, demonstrate their merits and demerits, and secure or lose a place in medicine. By slowness and silence, even with some active depreciation, the profession obtains the best results, and this without any unnecessary delay. The use and acceptation of a new and good operation has never been a simple proposal and jubilant reception, and should not be ; the whole matter must have time to ripen, and the special operation must exhibit plainly its qualities-what it can do, measured against what the corresponding disease does. "Sometimes, as when the issue of disease, not cancerous, is in all cases, or nearly all, certain early death, the problem to be solved is a comparatively easy one: death for all versus a certain amount of cure. But when there is uncertainty as to the nature, difference of opinion ás to the importance, or doubts as to the very existence of the disease to be remedied, the profession does well to be silent and slow. The problem to be solved is a difficult one; and if the operation puts.life in the balance, there is a heavy responsibility which demands. increased slowness and care.

The history of the operation of ovariotomy is often, one may say regularly, cited as a warning against silence and slowness of recognition; but it is quite otherwise, being a good example of an operation gradually and in due time gaining for itself a beneficent position of eminence. That theoretical and other mistakes were made in opposing it, may be very true; and theoretical mistakes made in supporting it too. But these neither hastened nor delayed the adoption of the operation in ordinary practice. As soon as it made a clear and sufficient saving of life, it was accepted enthusiastically everywhere, and not till then; and we cannot wish a better fate for any similar proposal. Even now, wherever there are not skilled ovariotomists, ovariotomy is not an accepted operation; the poor sufferers have life prolonged by avoiding it.

The proposer of a new operation should not expect his brethren to see it in the same light as he does. For him it is gilded, and he jealously guards and promotes it. His judgment of it is that of an enthusiast. The wise practitioner may discommend it, or he may abstain from recommending it; and the proposer is too ready to interpret this conduct as indicating disapproval of him and of his bold and original method, while it is really quite consistent with admiration, and even encouragement short of avowed approval. As evidence in favour of it gradually gets strength, so the practitioner at length is justified in making trial of it, and he may at last adopt it; and his slowness, differing as it does from the inventor's wishes, is wise, and not hostile to him.

Proposers of new operations have generally expended much labour, and ofttimes much money, in developing them; and the profession should, and does, admire the zeal and recompense the sacrifice, cren though it may reject the operation. But there is often too much expected by the zealous proposer, and too little care taken by the critics, even by those who are essentially kindly; to avoid injury to the natural sensitiveness of such proposers. Against these eriis we can only urge the force of moral obligations, which, though possibly too often in the mouth, cannot be too patent in the heart.

Dr. Duncan then asserted his belief that promoters of novel operations do not appear to attach the sams value to life as the profession generally. There is now a demand, in connexion with this matter, for the combined work of the surgeon and the actuary. Data might surely be obtained which would be sufficient to settle, appreximately, the value of life in the diseases calling for tooth-extraption, semoving of pites excision of the mamma, lithotomy, oöphorectomy, ovariotomy, hys terectomy, and others; and, on the other hamd, the danger of the operations themselves; and from the -two results; viewed in the light of established professional practice; might be deduced a scale of justifiable or of ordinarily incurred risk, which might facilitate and corroborate judgment as to the due proportion of danger in new operations. Already some limited computations of this kind have been made, but they have been done by spearal pleaders and are insufficient.

A well-conducted inquiry would lead to conolusions which might on the one hand, diminish our estimate of the value of life : or in crease our estimate of the importance of mere chronic ailing 6 or the inquiry might confirm the opinions on these subjects which are at present generally held. We might thus be able; with great as surance, to judge whether or not a mortality of one in five; or one in twenty, is to be 'encounterdd in 'an' operation for the relief' of mere chronic ailing; and so on, according to the gravity of the ailing, or the danger to life arising from the disease. 